\title{
Possibilities of theatrical pedagogy in solving problems of social sphere
}

\author{
Hana Strejčková ${ }^{*}$ \\ ${ }^{1}$ Academy of Performing Arts Prague, Nonverbal Theatre Department/Nonverbal and Comedy \\ Theatre and Theory of Theatre, Prague, Czech Republic
}

\begin{abstract}
In my article I focus on the connection between the artistic and social spheres, the transcendence of art education into therapy and I will briefly mention the structure of art education with a focus on theatrical pedagogy in the Czech Republic. I divided the article into theatrical pedagogy in practice for younger school age, teenage and youth, adults and seniors, and the following areas: a) Theatrical pedagogy in the structure of the Czech educational system and as a part of leisure activities and Drama education as a subject for future teachers. In this part I shortly present what drama education / theatrical pedagogy in the Czech school system means and I draw the introduction on the studies and ideas of prof. Mgr. Jaroslav Provazník, who leads the Department of Drama in Education at the Academy of Performing Arts in Prague; b) The potential of nonverbal theatre techniques in communication with specific groups and theatre pedagogy in the context of integration and inclusion; c) Pedagogy of substitute subjects - performativity of objects. In this section I present a personal description of one five-year cycle with "object workshops" drama education: empirical research, comparison, development of methodology of working with the subject in the context of drama education.
\end{abstract}

Keywords: drama education, theatrical pedagogy, physical theatre, object theatre.

\section{Introduction}

I see theatrical education/drama education as a creative pedagogy, a way to promote creativity and personal self-development, and this is essential at every stage of human life. In my pedagogical practice I focus on children and youth in the Theatre studio, as well on seniors in dance and drama therapy. I have many years of experience with activities for mentally handicapped people and other specific groups. Also, I am a theatre publicist specializing in physical theatre, new circus and theatre, as well as theatre pedagogy for children.

\footnotetext{
* Corresponding author: hanastrejckova@,seznam.cz
} 


\section{Methods}

Drama education is one of the five fields of aesthetic education and art education (in addition to literary, art, music and movement education).

Drama education is a pedagogical discipline which uses some techniques and procedures of theatrical art, because it works mainly with interpersonal relationships, situations (in which interpersonal relationships manifest themselves) and with transformation that comes from children's own, natural play, where "process is important, not the result" [1, p. 16], "like" - pretend - discover; the essence of this transformation is the action by which the participants in the game/play and everything that is part of it become something or someone other than they really are; this allows players to consciously create a fictional world - dramatic characters, storylines and environments.

Drama education is teaching primarily through direct experience and personal experience in negotiations, gaining life experience by looking for a solution to the problem (situation) not only with intellect, but also with the involvement of body and emotions.

Drama education is a system of activities that are purposefully arranged or structured into meaningful units. "Drama education places the child at the centre of the process. The student is perceived as a subject of the process $<\ldots>$. The focus is on caring for the process, its quality in relation to the child, its possibilities and horizons" [2].

Part of dramatic education is also the process of creating a stage production, or its public performance. However, it is not the goal of working with children, but a means of an educational process.

\section{Results}

I participate in teaching drama education at a secondary pedagogical school as a specialist from the field of professional theatre. We teach adolescent students to work with children and youth using drama education methods so that they will be able to structure a lesson, create a long-term plan and set goals.

During the school year 2018/2019, we implemented an annual project with students in the field of drama education at a secondary pedagogical school. The aim was to create a series of lessons for primary school children on the topic of environmental protection. As a source of inspiration, we offered students a short story by R. Bradbury. Firstly, we focused on the visualization of the ideas of the short story. We were drawing, working with the material (paper, stone, wooden sticks), and then we tried to motivate students to express their feelings through movement. "Openness and playfulness are made meaningful by students' ability to recognise how their movement through space resonates emotionally, dramatically and dynamically" [3, p. 169]. In the next phase, we offered them a staging process that uses the principles of drama education - especially play and imagination [4]. After rehearsing the performance, the students chose one part of the story and created a sample lesson in groups. We presented the performance only once. For this special event, we chose a theatre in a home for elderly people, where we also invited primary school pupils. Three generations met in the hall. They saw the performance together and discussed it. The students then visited the primary school and applied the lessons prepared by them in practice.

In connection with the target group, it is important that a lesson based on the principles of theatrical dramaturgy returns from art to comprehensible details and builds on touchable mundaneness. "The purpose is to select the optimal method to achieve the goal and to schedule different types of activities into the time and duration of the event so as to ensure coherence and gradation." [5, p. 105]. 
Now let us dwell on nonverbal theatre techniques in communication with specific groups and theatre pedagogy in the context of integration and inclusion. Drama education is irreplaceable here because it develops primary competencies that are directly related to the knowledge of theatrical art as a creative process and improve specific knowledge of the world. Having acquired the competencies, a pupil:

- perceives dramatic art as an independent kind of art and gets acquainted with its essence and laws;

- is familiar with the genres of dramatic art (not only theatrical, but also film, television and radio), gets acquainted with the historical stages and peculiarities of theatrical art and the social significance of theatre;

- understands the principles of interpersonal communication and uses its means adequately and understands the links between internal experience and external behaviour;

- through dramatic play and role-playing, explores and clarifies personal attitudes to selected topics focused primarily on interpersonal relationships, attitudes, values and societal issues;

- works in a group, actively participates in joint creation, its completion and presentation.

All these competencies in a creative process lead pupils and students to be active and creative people as well as cultured and receptive spectators. "Although the child distinguishes reality from play, with the help of objects and situations taken from the real world, he creates his own world, in which he can freely relive pleasant experiences or connect and change events in a way that brings him the greatest pleasure" [6, p. 27]. "We need/use/protect theatre as a subject in a pedagogical system of art education" [7], as integration, and as inclusion. "What unites us should not obscure what distinguishes" [8, p. 44].

We use the following methods in our practice, i.e. in theatrical pedagogy/drama therapy/drama education:

- drama, puppet and object theatre/performative object,

- adapted techniques of street and contemporary dance [9],

- movement analysis \& poetic body by Jacques Lecoq; method: away from telling and towards showing through experiencing [10, p. 175],

- mime and physical theatre methods,

- folklore dance, rhythm,

- Jacobson's method, basal stimulation, the art of touch,

- reminiscence theatre,

- social circus [11].

We worked with the following groups:

- Children 4-7 years old without and with specific needs (behavioural, neurological disorders, autism, physical disability, foreigners).

- Children 8-12 years old with specific needs.

- Youth (from socially disadvantaged environment, national minorities, mentally disabled people).

- Elderly people (incl. people with dementia, disabled people).

- Mixed groups (children, elderly people, disabled and disadvantaged).

Certain symptoms of these clients are affected by drama-therapy/drama education, such as anxiety, aggression, passivity, emotional misbalance, behavioural disorders.

We used such basic exercises/techniques as:

- BODY: breath, correction of sitting and standing position, spine relaxation, shoulder work, bends of the torso, hand exercises and foot plate work. 
- SPACE: relationship between space and me, me and the partner, me and the group. "There is an undoubted connection between our inner self and the space that surrounds us, in which we move, in which we live and which we understand as external. We carry the diverse landscapes of our lives at different depths. Landscape of home, apartment, place, house, road, street" [12, p. 63].

- RITUALS: their importance for every group or individual. "One of the fundamental pillars of the ritual is using a specific space-time. Through symbols and symbolic conduct, the ritual allows us to live through an important theme/situation safely outside the normal time and space" [13, p. 81].

- OBJECTS: manipulation - coordination: interest - improvement of abilities/psychomotor exercises to support brain and body connection.

Our work brings valuable improvements to the participants:

- awareness of self-mobility including the feeling of unification of body and soul,

- emotional spontaneity and reduced anxiety,

- improvement of nonverbal and verbal communication.

\section{Discussion}

Now let us move on to my personal description of one five-year cycle with "object workshops".

I have been teaching in the field of acting with the object since 2010. I aim at the performer relationship, mime - real object (on the seriousness of children playing with objects see [14]) - space. I will mention the experience from the Chrudim Puppet Festival, which I attended for five years in a row (2015-2019) as a lecturer at a weekly seminar. In the first year, I offered a group of about twenty participants the topic "Body, human and wood, in space and movement." We dealt with the transformation of the body into an object and the transformation of an object with the body, the transformation of the body into a range of colours and the transformation of space with movement and an object. We tested how a tangible body works in space and what an object (more on-stage objects: $[15,16]$ ) can do with space. Next, we looked for the triggering mechanism of the movement of the "figure" - the body of a person in walking.

A year later, we continued on the topic "Shapes and objects in motion." We examined space and an object in movement through itself. The final presentation on the stage of the K. Pippich Theatre in Chrudim was a show of the principles of work with object and space we examined. As a continuation, I announced a seminar entitled "Poetic body with and without threads". The aim of the week-long joint trip was to observe nature, identify with the elements and intuitively search for and examine objects that were capable of transforming by manipulation, movement. Part of the participants was getting acquainted with a neutral mask and the production of one's own symbolic mask, work on physicality in one's own mask and an effort to feel the "poetic body". For the fourth part I suggested touching on the essence, then I wrote the topic "Triptych of nonverbal communication: breath - look - touch". I emphasized the path from oneself to partner, to exploring the effect of emotions on the breath - the transformation of the breath through the basic circle of emotions [17]. We worked on relationships such as balance - centre of gravity grounding, internal and external motivation/impulse to risk, as well as on animating objects based on inspiration by sounds, music, stories, memories, space, partnership with man. Concepts have emerged for further research such as the contextualization of space by an object, or the recontextualization of an object by space (examples can be found in [18]).

So, what are the differences and similarities in working with children, youth and seniors including people with Alzheimer disease? Children are spontaneous, playful, curious, also 
closed, anxious, aggressive. Youth are very motivated or without interest, expressive and curious, but also closed, aggressive, violent, or very open. Seniors are motivated but tired, feeling pain but having energy to act. People with Alzheimer's are roaming around, restless, disinterest, resistance, but can be motivated, stimulated (examples can be found in [19]).

The value of it all is consciousness here and now - creating habit - cooperation in the sense of social feeling - joy and pleasure - aggression (anger) reduction - stimulation of the senses - positive provocation of dialogue and contact.

\section{Conclusion}

Art/drama education/drama-therapy is the right way to improve the lives of children with specific needs, youth from disadvantaged social environment, seniors with disability and dementia and to increase the human sensitivity of our society.

\section{References}

1. E. Machková, Jak se učí dramatická výchova [How to teach drama education] (AMU, Prague, 2007)

2. R. Marušák, O. Králová, V. Rodriguézová, Dramatická výchova v kurikulu současné školy [Drama Education in the Curriculum of the Current School] (Portál, Prague, 2008)

3. M. Evans, Theatre, Dance and Performance Training, 3, 163-177 (2012)

4. S. Kot’átková, et al., Vybrané kapitoly z dramatické výchovy [Selected chapters from drama education] (Karolinum, Prague, 1998)

5. J. Valenta, Divadlo nebo život! [Theatre or Life!] (KANT AMU, Prague, 2019)

6. S. Millarová, Psychologie hry [Psychology of Play] (Panorama, Prague, 1978)

7. M. Valenta, Dramaterapie [Dramatherapy] (Grada, Prague, 2011)

8. G. Banu, Nepodrobený herec [An unsubstantiated actor] (AMU, Prague, 2016)

9. S. Kwan, Dance Research Journal, 49, 38-52 (2017)

10. A. Frost, R. Yarrow, Improvisation in Drama, Theatre and Performance: History, Practice, Theory, $3^{\text {rd }}$ edition (Palgrave, London, 2016)

11. J. Spiegel, TDR/The Drama Review, 60, 50-67 (2016)

12. J. Vinař, Herec je svou vlastní možností. Pražská scéna [Actors Are Their Own Eventualities. Prague scene] (AMU, Prague, 2017)

13. H. Weule, M. Weule (Eds.), Among Heroes and Demons (HIT - heroes of inclusion and transformation, Bratislava, 2019)

14. J. Rapoport, Herec a jeho práce [The actor and his work] (Svoboda, Prague, 1946)

15. J. Veltruský, Slovo a slovesnost, ročník, 6(3), 153-159 (1940)

16. A. Sofer, Theatre Journal, 68(4), 673-684 (2016).

17. L. Růžičková-Šrejberová, Cycle of basic emotions in the method of the Hero's Path by Paul Rebillot, Diploma thesis (Palacký University in Olomouc, Olomouc, 2018)

18. C. Carrignon, How to use object (2013). Accessed on: December 16, 2020. [Online]. Available: http://www.puppetring.com/2013/02/21/how-to-use-object-theatre-bychristian-carrignon/ 
19. T. Fertal'ová, I. Ondriová, Demence: nefarmakologické aktivizační postupy [Dementia: non-farmacological activation methods] (Grada Publishing, Prague, 2020) 